\title{
PEMBERDAYAAN PRAJURU LEMBAGA KEUANGAN MIKRO ADAT MELALUI PENERAPAN TEKNOLOGI INFORMASI DI DESA KESIUT KECAMATAN KERAMBITAN KABUPATEN TABANAN
}

\author{
Oleh \\ Putu Krisna Adwitya Sanjaya, I Nyoman Suta Widnyana, I Putu Nuratama \\ Fakultas Ekonomi Bisnis dan Pariwisata, Universitas Hindu Indonesia \\ Email : Krisnasanjaya50@yahoo.co.id
}

\begin{abstract}
Indonesia is preparing itself in the era of the industrial revolution 4.0. For this reason, businesses are expected to be able to maximize the use of information technology to the fullest, one of which is by preparing financial statements. But now there are not many microfinance institutions that use information technology to carry out the recording of their financial statements. This also happened in Kesiut village, located in Kerambitan sub-district, Tabanan Regency. The Indigenous Community microfinance institution still records finances manually and some even inconsistencies in carrying out the registration process. Of course this if not followed up immediately will pose a risk of future losses. The obstacle faced is the lack of professional quality human resources. Problem solving solutions are implemented by conducting socialization, training and assistance in preparing financial statements. The implementation method is carried out in several stages, beginning with providing an understanding of the importance of the use of information technology, followed by giving an overview of the general picture of how the industrial revolution occurred which could lead to diseruption. The next step is to carry out training in preparing financial statements based on information technology software. The final stage is assisted to help solve the problems faced in relation to the preparation of financial statements. Through the community partnership program which is manifested through the stages of outreach, training and mentoring, the Indigenous community microfinance institution in running its business is able to independently prepare financial reports and conduct evaluations of its business activities. By carrying out this activity it is also hoped that in the long run the Indigenous community microfinance institutions in the Kesiut village will further develop and of course with the development of indigenous community microfinance institutions, the economy in the area will also be stretched so that there will be an acceleration of the welfare of the village community.
\end{abstract}

Keywords: Training, Assistance, Financial Reports, Information Technology, Indigenous Community Microfinance Institutions. 


\section{Pendahuluan}

Indonesia saat ini sedang bersiap menghadapi revolusi industri generasi ke 4, hal ini sering disebut revolusi industry 4.0. Revolusi Industri 4.0 ditandai dengan digunakannya beragam teknologi canggih seperti seperti kecerdasan buatan, Internet, robotika canggih, dan 3D printing. Dalam era digital seperti saat ini dibutuhkan kemampuan yang berbeda dibandingkan era sebelumnya. Penguasaan tekologi informasi menjadi sangat penting dalam era ini. Hoedi dan Wahyudi (2018) menyatakan bahwasannya pola kerjasama antara dunia akademik dan industri sangat diperlukan untuk mempercepat realisasi Industri 4.0. Revolusi industry 4.0 diprediksi akan membawa dampak negatif ekonomi. Dampak negatif ini terjadi terutama pada negara-negara berkembang yang tingkat kesenjangan sosial dan ekonominya masih relatif tinggi.

Untuk menghindari dampak negatif yang mungkin terjadi, masyarakat mau tidak mau suka tidak suka harus mengimplementasikan teknologi informasi kedalam kegiatan mereka, jika tidak maka akan semakin tertinggal jauh. Revolusi industri juga memunculkan ekonomi berbasis teknologi atau yang lebih dikenal dengan ekonomi digital (Hendra, 2017). Untuk itu maka pelaku usaha harus mulai menerapkan system digital dalam menjalankan kegiatannya. Banyak sekali peranan teknologi informasi diantaranya adalah dapat meningkatkan tranformasi bisnis melalui kecepatan, ketepatan dan efisiensi pertukaran informasi dalam jumlah yang besar. Arief (2009) menyimpulkan dalam makalahnya bahwa salah satu strategi untuk meningkatkan dasa saing usaha berbasis mikro adalah melalui pemanfaatan teknologi informasi.

Lembaga Keuangan Mikro yang ada di Provinsi Bali khususnya di Desa kesiut yang dijalankan berdasarkan komunitas adat atau yang disebut dengan Lembaga Perkreditan Desa (LPD) merupakan lembaga keuangan yang dimiliki oleh Desa Adat yang mejalankan aktifitas usaha dalam bidang layanan keuangan dengan produk utama adalah deposito, tabungan dan kredit. Dijalankan secara simultan atas pengawasan dari pemerintah dan Bank Pembangunan 
Jurnal Sewaka Bhakti

Lembaga Penelitian dan Pengabdian Kepada Masyarakat

Universitas Hindu Indonesia Denpasar

Volume 3, Nomor 1 Oktober 2019

ISSN: 2654-2935 (Online)

https://ejournal.unhi.ac.id/index.php/sewakabhakti

pp.25-39

Daerah dengan bersinergi dengan Badan Kerjasama Lembaga Perkreditan Desa Provinsi Bali. Guna membantu aktifitas krama desa maupun juga sebagai sumber pemasukan bagi desa adat yang digunakan untuk menjalankan aktifitas pembangunan desa termasuk juga untuk melestarikan adat, budaya dan tradisi desa setempat.

Lembaga keuangan mikro komunitas adat di Desa Kesiut yang memiliki prospektif baik perlu sentuhan manajemen dan teknologi yang tepat untuk lebih mampu meningkatkan sumbangsihnya bagi penggerak perekonomian desa dimana ada beberapa analisis masalah yang dijumpai di lapangan yakni : (a) Lembaga Perkreditan Desa Adat Kesiut belum sepenuhnya memanfaatkan Teknologi Informasi untuk menyusun laporan keuangan. (b) Pencatatan keuangan masih sangat sederhana bahkan ada yang masih manual dengan melakukan pencatatan pada buku tulis. (c) Lembaga Perkreditan Desa Adat Kesiut belum memiliki visi misi yang jelas dan juga tidak memiliki perencanaan anggaran, sehingga mereka tidak mengetahui akan jadi seperti apa usaha mereka dan juga karena tidak dibuatnya anggaran maka sulit mengukur capaian telah diperoleh.

Berdasarkan penjelasan diatas, maka dipandang perlu untuk memberdayakan prajuru LPD yang dikejawantahkan melalui pelatihan dan pendampingan dalam hal penggunaan teknologi informasi untuk menyusun laporan keuangan serta pendampingan dalam penyusunan anggaran lembaga. Dengan diadakannya pelatihan dan pendampingan ini diharapkan lembaga keuangan mikro komunitas Adat di Desa Kesiut dapat berkembang sesuai yang diharapkan mengingat bagi sebagian besar masyarakat adat roh dari perekonomian adalah Lembaga Perkreditan Desa itu sendiri .

\section{Metode Pelaksanaan}

Kegiatan Pengabdian Masayarakat ini dilaksanakan di Desa Kesiut yang terletak di kecamatan Kerambitan, Kabupaten Tabanan, Provinsi Bali, Indonesia, dengan menyasar lembaga keuangan mikro komunitas adat atau Lembaga Perkreditan Desa (LPD) di Desa Kesiut dengan bidang usaha keuangan yang dijalankan. Persiapan dilakukan dengan melakukan koordinasi dan sosialisasi kegiatan meliputi pertemuan koordinasi dengan pihak aparat Desa (Perbekel), Jero Bendesa, Pimpinan LPD Kesiut Arca dan LPD Kesiut Tengah 
serta beberapa penglingsir maupun tokoh masyarakat setempat mengenai pelaksanaan program ini. Adapun tahapan pelaksanaan kegiatan adalah sebagai berikut :

a. Melaksanakan sosialisasi dan diskusi

Kegiatan Sosialisasi dan diskusi dilakukan kepada manajemen lembaga (prajuru) keuangan mikro mengenai pentingnya penggunaan teknologi informasi dalam menjalankan usaha, terutama untuk melaksanakan pencatatan dan penyusunan laporan keuangan. Hal ini penting untuk dilakukan agar terbentuk paradigma baru bahwa penggunaan teknologi informasi itu sangatlah penting terutama di era digitalisasi seperti sekarang ini.

b. Melaksanakan pemaparan mengenai revolusi industri 4.0.

Kegiatan ini dilakukan bertujuan untuk memberikan gambaran bagaimana revolusi industri terjadi di era ini, sehingga diharapkan akan semakin menggugah peserta dalam memanfaatkan teknologi informasi dalam menjalankan usahanya.

c. Pemberdayaan prajuru dalam mengelola program Pemberdayaan prajuru dilakukan dengan memberikan pengetahuan, pelatihan dan pendampingan didalam menjalankan aktifitas manajemen operasional Lembaga Perkreditan Desa yakni dimulai dengan mengenalkan serta memberikan software akuntansi dan melaksanakan pelatihan penggunaan software akuntansi untuk menyusun laporan keuangan. Setelah software di berikan kemudian tim Pelaksana melakukan penginstallan di lokasi kegiatan (LPD Desa Adat Kesiut Arca dan LPD Desa Adat Kesiut Tengah) serta memberikan penjelasan awal atau pengantar atas tata cara penginstallan maupun gambaran umum atas software yang digunakan dalam pelatihan ini dilakukan sebagai bentuk memberi pemahaman dan kesepahaman atas fungsi dari pada teknologi didalam membantu memudahkan pengoperasionalan kegiatan usaha.

d. Pemberdayaan prajuru di dalam menyusun visi misi organisasi dan penyusunan anggaran

Pemberdayaan prajuru LPD dilakukan pula dengan melaksanakan pelatihan penyusunan visi dan misi serta penyusunan anggaran. Di dalam Pelatihan ini prajuru 
Jurnal Sewaka Bhakti

Lembaga Penelitian dan Pengabdian Kepada Masyarakat

Universitas Hindu Indonesia Denpasar

Volume 3, Nomor 1 Oktober 2019

ISSN: 2654-2935 (Online)

https://ejournal.unhi.ac.id/index.php/sewakabhakti

pp.25-39

akan dibimbing langsung untuk menyusun visi dan misi usaha mereka. Setelah mereka mampu menyusun visi dan misi dilanjutkan dengan pelatihan menyusun anggaran.

e. Pendampingan program

Pendampingan program dilakukan setelah kegiatan pelatihan dilaksanakan. Kegiatan pendampingan ini dilaksanakan untuk membantu pihak manajemen dalam menghadapi kendala-kendala saat melakukan pencatatan menggunakan software. Selain itu dalam kegiatan ini juga dilaksanakan penyandingan antara realisasi yang terjadi sehingga prajuru dapat mengetahui bagaimana capaian yang telah mereka peroleh.

\section{Hasil dan Pembahasan}

\subsection{Urgensi Sosialiasi terhadap Penggunaan Teknologi informasi dalam Proses Penyusunan Laporan Keuangan}

Untuk mensosialisasikan pentingnya penggunaan teknologi informasi dalam menyusun laporan keuangan, maka dilaksanakanlah program sosialisasi yang berlokasi di Balai pertemuan kantor Perbekel Desa Kesiut, Kecamatan Kerambitan, Kabupaten Tabanan, Provinsi Bali. Adapun Judul yang dibawakan dalam acara sosialisasi ini adalah Pelatihan dan Pendampingan Penyusunan Keuangan Berbasis Teknologi Informasi Pada Lembaga Keuangan Komunitas Adat di Desa Kesiut. Acara sosialisasi ini dihadiri oleh 16 orang peserta yang terdiri dari pengurus LPD desa Adat, Pengawas, Jero Bendesa, Tokoh Masyarakat, Aparat Desa setempat.

Pelaksanaan sosialisasi ini berlangsung pada hari Senin 19 Agustus 2019 yang bertempat di Balai Pertemuan Kantor Perbekel Desa Kesiut. Pelaksanaan sosialisasi berlangsung selama kurang lebih 150 menit dan lebih banyak berlangsung diskusi mengenai keinginan pengurus untuk mengembangkan LPD agar dapat meningkat dan semakin baik kedepannya baik dalam hal tata kelola, aset (keuangan) maupun berkontribusi nyata dalam proses pembangunan desa setempat. Gambar 3.1 Menunjukkan aktivitas kegiatan sosialisasi dengan pemaparan materi akan pentingnya penggunaan teknologi informasi serta kegiatan sosialisasi lebih banyak diisi dengan sharing maupun diskusi atas problem - problem yang selama ini terjadi pada LPD Desa Adat Kesiut Arca maupun LPD Desa Adat Kesiut Tengah. 
Jurnal Sewaka Bhakti

Lembaga Penelitian dan Pengabdian Kepada Masyarakat Universitas Hindu Indonesia Denpasar Volume 3, Nomor 1 Oktober 2019 ISSN: 2654-2935 (Online) https://ejournal.unhi.ac.id/index.php/sewakabhakti pp.25-39

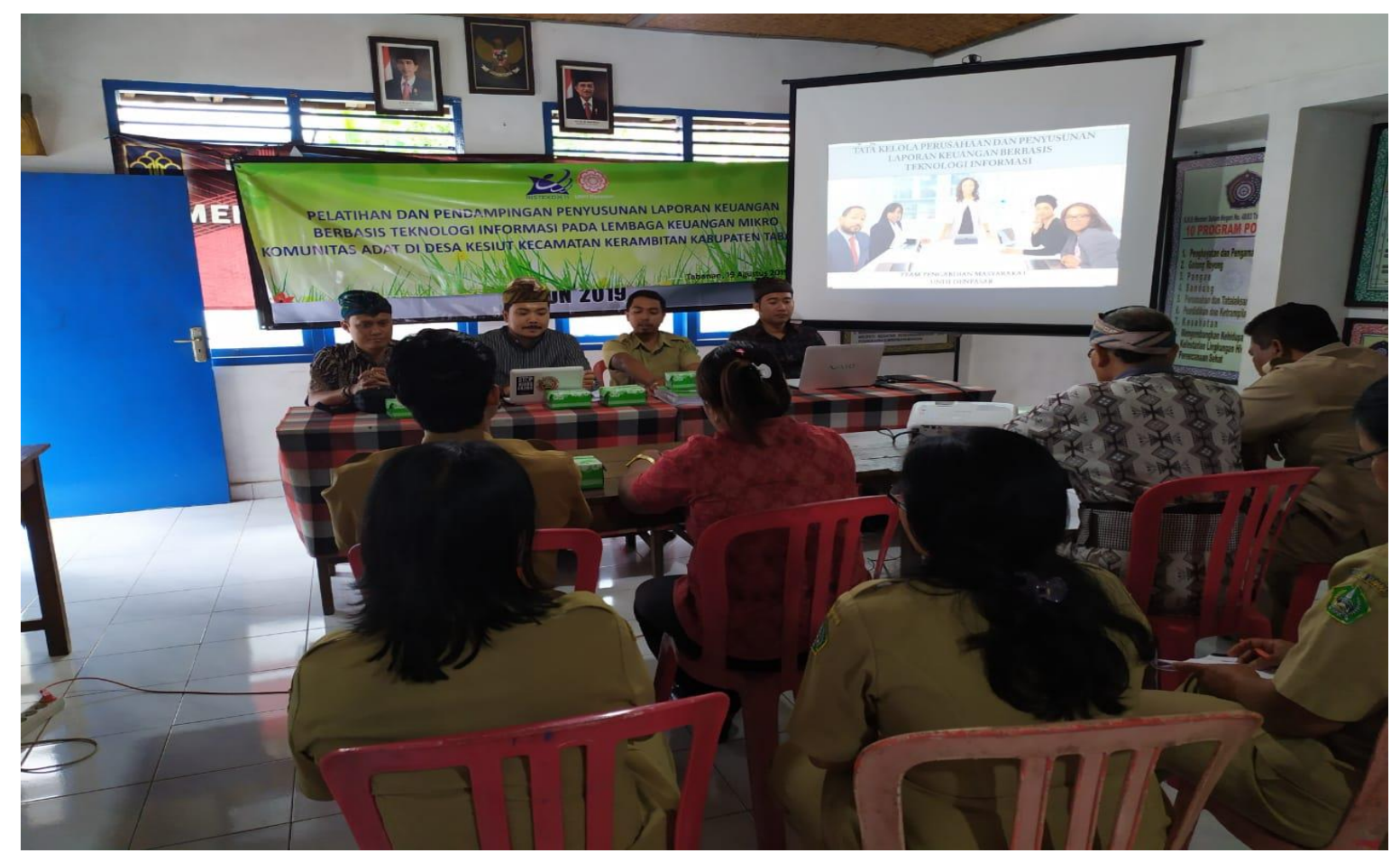

Gambar 3.1 (a) Pemaparan Materi Sosialisasi

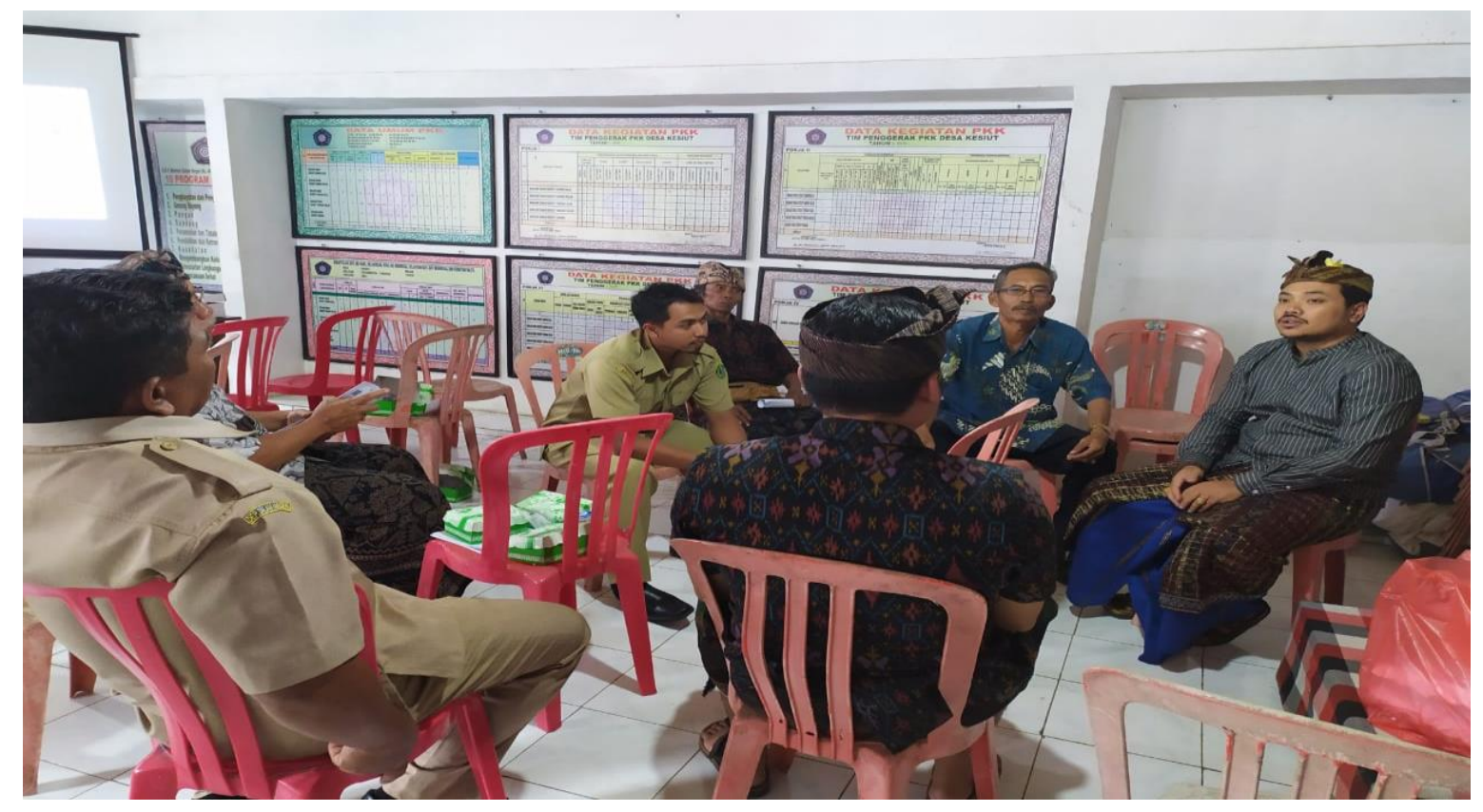

Gambar 3.1 (b) Aktifitas Edukasi dan diskusi terbatas tentang pentingnya penggunan Teknologi Informasi pada kegiatan usaha 
Teknologi Informasi secara prinsipil adalah suatu item teknologi yang digunakan untuk mengolah data, termasuk memproses, mendapatkan, menyusun, menyimpan, memanipulasi data dalam berbagai cara untuk menghasilkan informasi yang cepat, akurat dan berkualitas. Suatu sistem teknologi informasi wajib mendukung tujuan utama suatu entitas bisnis yakni mencapai profit. Tujuan sistem informasi dari suatu entitas bisnis haruslah selaras dan terintegrasi sehingga sistem mampu mendukung tujuan yang ingin dicapai. Selanjutnya informasi jadi bernilai apabila telah dianalisis dengan cermat. Perangkat lunak atau software yang digunakan untuk menghasilkan informasi harus mencocokan dengan bisnis proses perusahaan yang dimaksud.

Penyusunan sistem informasi keuangan suatu entitas bisnis juga mempunyai beberapa tujuan yang harus dipertimbangkan dengan baik, yakni :

a. Sistem Informasi Keuangan yang disusun itu harus memenuhi prinsip cepat yaitu bahwa Standar Akuntansi Keuangan harus mampu menyediakan data yang diperlukan tepat pada waktunya dan dapat memenuhi kebutuhan.

b. Sistem Informasi keuangan yang disusun itu harus mempunyai prinsip aman yang berarti bahwa Sistem Informasi keuangan harus membantu menjaga harta milik perusahaan, untuk dapat menjaga keamanan harta milik perusahaan maka Sistem Informasi Akuntansi Keuangan (SIAK) harus disusun dengan pertimbangan pengawasanpengawasan intern.

c. Sistem informasi keuangan yang disusun harus mempunyai prinsip murah yang berarti bahwa biaya untuk menyelenggarakan Sistem Informasi keuangan ini harus dapat ditekankan sehingga relatif tidak mahal.

Model sistem informasi keuangan berbasis teknologi yaitu subsistem input dan subsistem output. Sistem informasi keuangan mencakup tiga subsistem output yaitu subsistem peramalan, subsistem manajemen dana, subsistem pengontrolan. Sedangkan untuk input terdiri dari subsistem finance intelegent, subsistem audit keuangan, dan subsistem pemrosesan transaksi. Untuk bagian keuangan atau bendahara dalam suatu entitas bisnis, sistem informasi ini dapat digunakan dalam menentukan jenis keputusan investasi apakah jangka panjang atau jangka 
Jurnal Sewaka Bhakti

Lembaga Penelitian dan Pengabdian Kepada Masyarakat

Universitas Hindu Indonesia Denpasar

Volume 3, Nomor 1 Oktober 2019

ISSN: 2654-2935 (Online)

https://ejournal.unhi.ac.id/index.php/sewakabhakti

pp.25-39

pendek, serta manajemen keuangan dapat menggunakannya untuk menstabilkan atau menyeimbangkan kondisi keuangan (Krisna, 2019).

\subsection{Upaya Peningkatan Keterampilan Prajuru melalui Pelatihan dan Pendampingan dalam memanfaatkan Teknologi Informasi}

Era revolusi industri 4.0. menuntut pelaku usaha untuk mampu memaksimalkan penggunaan teknologi informasi dengan maksimal yang salah satunya adalah dalam melakukan penyusunan laporan keuangan. Namun saat ini tidak banyak lembaga keuangan mikro yang menggunakan teknologi informasi untuk melaksanakan pencatatan laporan keuangannya, termasuk Mitra sasaran dalam kegiatan Pengabdian Kepada Masyarakat ini.

Lembaga keuangan mikro Komunitas Adat Kesiut Arca dan Kesiut Tengah masih mencatat keuangan mereka secara manual dalam melakukan proses pencatattan. Seperti yang terekam dalam gambar 3.2 dan 3.3 berikut :
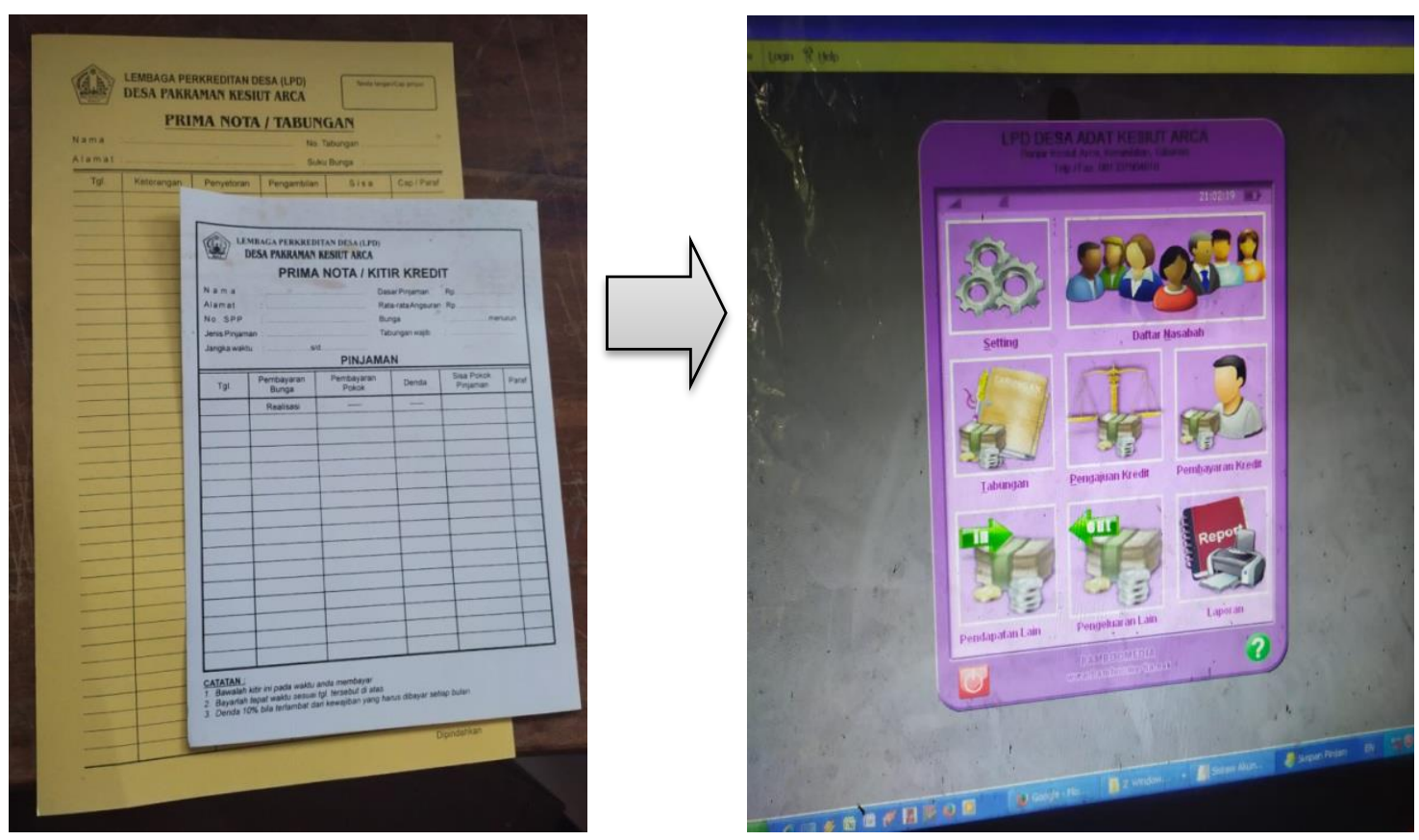

Gambar 3.2 Pencatatan Keuangan LPD Desa Adat Kesiut Arca a. Manual Sistem

b. Berbasis Teknologi Informasi (setelah diberikan software) 

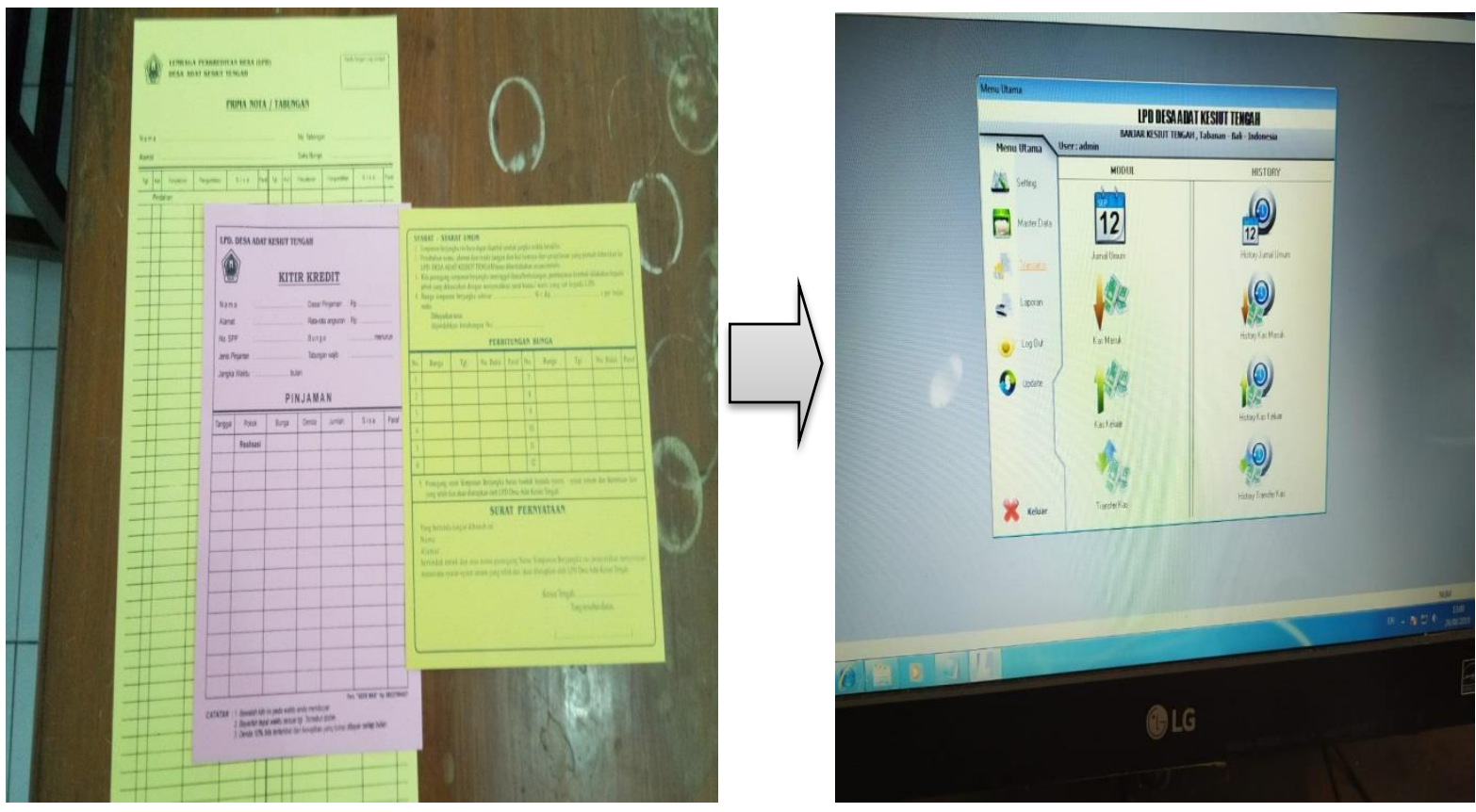

Gambar 3.3 Pencatatan Keuangan LPD Desa Adat KesiutTengah

a. Manual Sistem

b. Berbasis Teknologi Informasi (setelah diberikan software)

Pada gambar 3.2 dan 3.3 point (a) diatas kedua mitra sasaran masih mempergunakan manual sistem dalam proses pencatatan keuangannya hal ini dikarenakan kurangya sumber daya manusia yang handal dan profesional. Solusi pemecahan masalah dilaksanakan dengan melakukan sosialisasi, pelatihan dan pendampingan penyusunan (pencatatan) laporan keuangan berbasis teknologi informasi. .

Peningkatan kualitas mutu modal sumber daya manusia dengan cara memberikan sosialisasi, pelatihan maupun pendampingan untuk mendapatkan berbagai keperluan yang berhubungan dengan upaya untuk pemberdayaan maupun ekspansi usaha Lembaga Perkreditan Desa bila dimungkinkan. Hal tersebut diyakini sebagai sebuah upaya untuk meningkatkan pengetahuan dan skills miitra pengabdian dalam hal memperkuat tata kelola lembaga keuangan yang profesional dan akuntabel.

Penerapan teknologi informasi sangat urgent untuk dilaksanakan mengingat teknologi informasi memiliki peran strategis bagi tata kelola maupun pengembangan suatu entitas bisnis, terutama dalam bidang Akuntansi. Peranan teknologi informasi dalam bidang akuntansi 
misalnya meningkatkan efisiensi dan efektifitas, mengembangkan kinerja perusahaan, untuk perlindungan asset dan meningkatkan produktivitas, mempermudah pekerjaan.

Apabila perusahaan memanfaatkan teknologi informasi dalam pengelolaan akuntansinya maka pengerjaan siklus akuntansi diatas menjadi semakin mudah dan cepat. Ada banyak keuntungan yang bisa diperoleh, seperti misalnya produktifitas karyawan semakin meningkat karena tugas menyusun laporan lebih singkat maka karyawan memiliki tambahan waktu untuk mengerjakan pekerjaan yang lainnya. Keuntungan lainnya adalah catatan lebih rapi, meminimalisasi kesalahan, memudahkan control terhadap catatan dan lain sebagainya.

Manajemen operasional Lembaga Perkreditan Desa (LPD) pada prinsipnya sama seperti lembaga keuangan bank. Proses bisnisnya mulai dari menghimpun dana masyarakat dan menyalurkannya sebagai kredit. Tentu dalam proses ini ada hal-hal yang perlu di perhatikan. Misalnya dana untuk masyarakat yang dihimpun tentu akan mendapatkan imbal berupa bunga, bunga ini wajib dibayarkan oleh LPD. Saat penyaluran kredit, ada kewajiban dari nasabah peminjam untuk membayar bunga. Baik bunga tabungan dan bunga simpanan tentu harus dicatat dengan teliti oleh bagian akuntansi. Kesalahan pencatatan tentu berisiko membuat kerugian bagi LPD (Widani dkk., 2018). Selain itu LPD juga harus melakukan kontrol terhadap kredit yang disalurkan, control disini dimaksudkan agar LPD terdindar dari kredit macet. Pencatatan yang kurang baik dapat menyebabkan LPD tidak mampu mengidentifikasi nasabah yang lupa menunaikan kewajibannya, sehingga merugikan LPD. Apabila pencatatan dilakukan secara manual maka semakin banyaknya nasabah maka risiko kesalahan menjadi semakin tinggi. Seharusnya risiko kerugian seperti ini dapat ditanggulangi dengan melakukan pencatatan yang baik dengan menggunakan teknologi informasi.

Dengan memanfaatkan teknologi informasi, maka pencatatan dan pembuatan laporan akan dapat dilakukan secara efektif dan efisien, sehingga akan dapat memunculkan banyak revenue seperti berkurangnya biaya tenaga kerja, penghematan penggunaan kertas, menghemat ruang penyimpanan karena banyak laporan disimpan dalam hardisk, ketepat waktuan dalam membuat laporan keuangan dan laporan analisa lainnya, ketelitian dalam pencatatan, memudahkan perhitungan bunga, baik bunga simpanan maupun bunga pinjaman, memudahkan dalam mencari data nasabah dan berapa saldo nasabah tersebut sehingga hal ini dapat meningkatkan kepuasan nasabah. 
Jurnal Sewaka Bhakti

Lembaga Penelitian dan Pengabdian Kepada Masyarakat

Universitas Hindu Indonesia Denpasar

Volume 3, Nomor 1 Oktober 2019

ISSN: 2654-2935 (Online)

https://ejournal.unhi.ac.id/index.php/sewakabhakti

pp.25-39

Penggunaan teknologi informasi juga dapat membantu proses monitoring. Dengan menggunakan software akuntansi untuk melakukan pencatatan maka akan memudahkan LPD untuk malakukan proses monitoring. Monitoring dilakukan dengan melihat umur piutang dari nasabah, sehingga apabila ada indikasi piutang nasabah tersebut bermasalah, maka LPD segera dapat melakukan tindakan. Pemanfaatan tenknologi informasi ini akan meningkatkan pengendalian intern perusahaan

\subsection{Pemberdayaan Mitra Sasaran dalam Menyusun Visi - Misi Lembaga dan Penyusunan Anggaran}

\subsubsection{Penyusunan Visi dan Misi Lembaga}

Visi adalah pernyataan yang diucapkan atau ditulis hari ini, yang merupakan proses manajemen saat ini yang menjangkau masa yang akan datang (Akdon, 2016). Visi merupakan gambaran masa depan yang ingin diwujudkan dalam kurun waktu tertentu. Menentukan visi merupakan hal yang sangat penting karena merupakan gambaran untuk seluruh anggota organisasi untuk melangkah bersama. Apabila visi tidak dibuat, maka anggota organisasi tidak mengetahui mau jadi seperti apa organisasi tersebut sehingga akan kesulitan bertindak atau tidak mengerti arah organiasi atau bahkan tidak mampu bersinergi antar anggota karena tidak satu pemahaman (Krisna, 2018).

Adapun hal yang dilakukan oleh tim Pelaksana pengabdian masyarakat adalah memberikan pemahaman pentingnya menyusun visi dan misi di perusahaan dalam suatu format diskusi kecil, yang didalamnya terdapat stakeholder yang berkepentingan terhadap lembaga keuangan mikro di Desa Adat Kesiut, kecamatan kerambitan kabupaten Tabanan. Para hadirin dalam diskusi tersebut diberi pemahaman pentingnya visi dan misi di perusahaan dan dampaknya terhadap kelangsungan dan perkembangan perusahaan.

\subsubsection{Penyusunan Anggaran}

Anggaran (budget) adalah merupakan rencana tertulis mengenai kegiatan suatu organisasi yang dinyatakan secara kuantitatif untuk jangka waktu tertentu dan umumnya dinyatakan dalam satuan uang, tetapi dapat juga dinyatakan dalam satuan barang atau jasa (M. 
Jurnal Sewaka Bhakti

Lembaga Penelitian dan Pengabdian Kepada Masyarakat

Universitas Hindu Indonesia Denpasar

Volume 3, Nomor 1 Oktober 2019

ISSN: 2654-2935 (Online)

https://ejournal.unhi.ac.id/index.php/sewakabhakti

pp.25-39

Nafarin, 2015). Karena berbentuk angka atau satuan moneter, maka anggaran ini biasanya disebut anggaran keuangan.

Mitra Sasaran diketahui telah melakukan penyusunan anggaran. Penyusunan anggaran dilakukan oleh Pengurus LPD dan dituangkan dalam suatu Laporan Rencana Kerja dan Rencana Anggaran yang dibuat setiap tahun. Adanya anggaran yang telah dibuat secara berkesinambungan tentu hal yang sangat baik bagi lembaga ini. Namun setelah digali lebih jauh, ternyata anggaran belum dimanfaatkan dengan maksimal untuk tujuan kordinasi antar personel organisasi di LPD tersebut, sehingga manfaat anggaran tidak maksimal diperoleh LPD. Anggaran hanya dibuat sebagai pemenuhan persyaratan yang diminta Lembaga Pemberdayaan Lembaga Perkreditan Desa (LPLPD) yang herus dilaporkan setiap tahun. Karyawan tidak mengetahui berapa target yang direncanakan perusahaan dan tentunya tidak ditarget untuk mencapai anggaran yang telah disusun sehingga anggaran belum dapat digunakan sebagai alat kordinasi. Faktor pendidikan dan peran pendidikan tinggi sangat diperlukan disini. (Sastra Wibawa, 2016)

Tim Pelaksana Program Kemitraan Masyarakat melakukan penyuluhan mengenai pentingnya anggaran dan manfaatnya kepada seluruh kepala LPD dan Pengawas Internal di Desa Adat Kesiut. Penyuluhan dilakukan satu persatu saat melakukan kegiatan pendampingan. Kegiatan ini dilakukan dengan harapkan bahwa kepala LPD akan memanfaatkan anggaran sebagai alat yang sangat bagus untuk berkordinasi antar angota LPD dan membuat LPD makin berkembang dan maju dari waktu ke waktu. Selain itu edukasi juga dilakukan oleh tim pelaksana untuk memberi pemahaman mengenai bagaimana memanfaatkan anggaran untuk melakukan pengendalian manajemen dan juga menilai kinerja, sehingga stakeholder dan pengawas internal dapat memantau kinerja manajemen dari waktu ke waktu. Gambar 3.4 memvisualisasikan aktifitas edukasi penyusunan anggaran Mitra sasaran. 

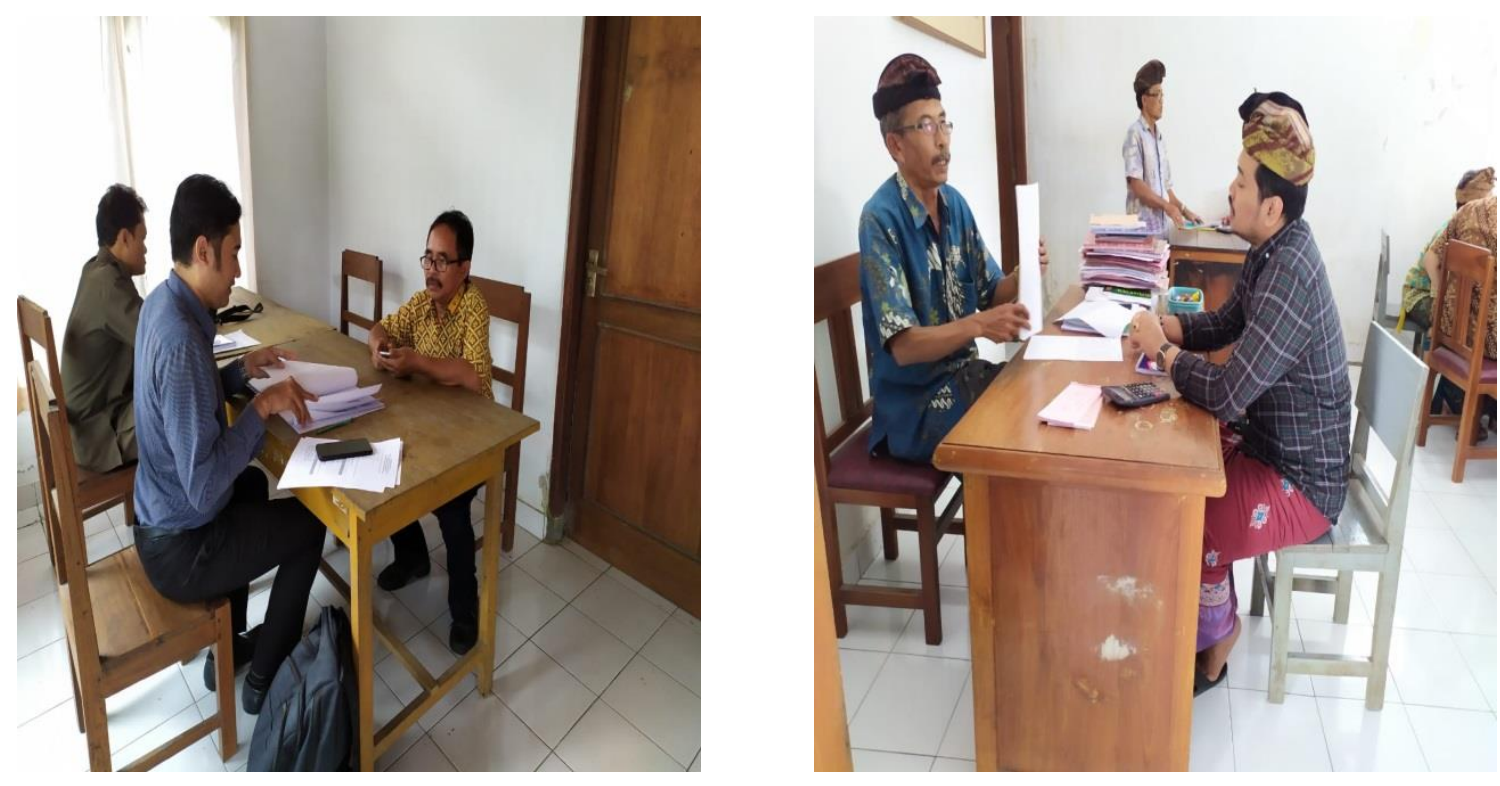

Gambar 3.4 Aktivitas Tim Pelaksana dalam memberikan edukasi/tutorial dalam merencanakan anggaran bagi Mitra Sasaran

\section{Penutup}

\section{Simpulan}

Telah dilaksanakan kegiatan pengabdian kepada masyarakat dengan basis Program Kemitraan Masyarakat dengan mitra sasaran adalah Prajuru Lembaga Komunitas Adat di Desa Kesiut Kecamatan Kerambitan Kabupaten Tabanan. Beberapa hal yang dapat disimpulkan setelah kegiatan ini dilaksanakan adalah sebagai berikut :

1. Sosialisasi melalui media penyampaian materi dan diskusi serta membangun suasana dialogis dipandang menjadi solusi utama sebagai upaya untuk mengakselerasi pemahaman mitra sasaran dalam hal ini Lembaga Perkreditan Desa Adat Kesiut Arca maupun Kesiut Tengah terhadap pentingnya pemanfaatan teknologi informasi yang diyakini mampu melakukan proses pengolahan data menjadi informasi yang holistik yang pada akhirnya menjadi semacam pengetahuan sehingga dapat digunakan sebagai 
Jurnal Sewaka Bhakti

Lembaga Penelitian dan Pengabdian Kepada Masyarakat

Universitas Hindu Indonesia Denpasar

Volume 3, Nomor 1 Oktober 2019

ISSN: 2654-2935 (Online)

https://ejournal.unhi.ac.id/index.php/sewakabhakti

pp.25-39

bagian dari proses untuk mengambil keputusan sehingga keputusan yang di ambil terstruktur, tersistem dan terencana (executive information system).

2. Sebagai suatu strategi untuk meningkatkan kemampuan prajuru mitra sasaran selain dengan media sosialisasi juga dilakukan pemberian software berbasis teknologi informasi, aktifitas pelatihan dan pendampingan untuk memperkuat tata kelola lembaga keuangan yang profesional dan akuntabel mengingat Lembaga Perkreditan Desa merupakan roh_nya perekonomian desa Adat yang ada di Pulau Dewata Bali.

\section{Rekomendasi}

Oleh karena kegiatan pengabdian ini sangat bermanfaat bagi mitra sasaran dalam hal meningkatkan pengetahuan maupun manajerial skills maka dipandang perlu untuk dilakukan kegiatan pelatihan maupun pendampingan lanjutan yang berkesinambungan mengingat implementasi penggunaan teknologi informasi sangat penting dan strategis untuk dilakukan karena teknologi informasi memiliki peran vital bagi tata kelola maupun pengembangan suatu lembaga keuangan seperti Lembaga Perkreditan Desa terlebih dalam era 4.0 ini.

\section{Ucapan Terimakasih}

Terimakasih kami sampaikan kepada Kementerian Riset Teknologi dan Pendidikan Tinggi Republik Indonesia yang telah mempercayakan, mendukung dan memberi bantuan hibah program kemitraan masyarakat ini. Terimakasih yang tulus juga diberikan kepada Lembaga Penelitian dan Pengabdian Masyarakat (LP2M) Universitas Hindu Indonesia atas dukungan serta fasilitasi selama program kemitraan masyarakat ini berlangsung. Matur Suksma dahat kami haturkan kepada Aparat Desa Kesiut Tabanan, Jero Bendesa Desa Kesiut, Prajuru Lembaga Perkreditan Desa Adat Kesiut Arca, Lembaga Perkreditan Desa Adat Kesiut Tengah selaku mitra sasaran dan segenap komponen Masyarakat Desa Kesiut serta semua pihak yang telah mendukung sehingga kegiatan ini dapat terlaksana dengan baik dan semoga apa yang telah di programkan dalam kegiatan ini dapat memberi sumbangsih bagi kemajuan LPD setempat. Astungkara ... 
Jurnal Sewaka Bhakti Lembaga Penelitian dan Pengabdian Kepada Masyarakat Universitas Hindu Indonesia Denpasar Volume 3, Nomor 1 Oktober 2019 ISSN: 2654-2935 (Online)

https://ejournal.unhi.ac.id/index.php/sewakabhakti pp.25-39

\section{Daftar Pustaka}

1. Arief, Rahmana. 2009. Peranan Teknologi Informasi Dalam Peningkatan Daya Saing Usaha Kecil Menengah. Seminar Nasional Aplikasi Teknologi lnformasi.

2. Akdon. 2006. Strategic Management For Educational Management. Alfabeta: Bandung

3. Anthony dan Govindarajan. 2004. Management Control System Salemba Empat: Jakarta

4. Didit Herlianto. 2015. Anggaran Keuangan. Gosyen Publishing: Yogyakarta

5. Gunawan dan Marwan. 2013. Anggaran Perusahaan Buku 1 edisi 2. BPFE: Yogyakarta.

6. Hendra, Suwardana. 2017. Revolusi Industri 4. O Berbasis Revolusi Mental. Jati Unik. Vol.1, No.2, Hal. 102-110.

7. Hoedi, Wahyudi. 2018. Industri 4.0: Telaah Klasifikasi Aspek Dan Arah Perkembangan Riset. Jurnal Teknik Industri. Undip.

8. Horgen, Charles T. Harrison Jr, Walter T. 2007. Akuntansi. Edisi ketujuh. Erlangga: Jakarta.

9. Kementerian Perindustrian Republik Indoneisa. Making Indonesia 4.0.

10. Marshall B. Romney, Paul John Steinbart. 2014. Sistem Informasi Akuntansi. Edisi 13. Salemba Empat: Jakarta.

11. Nafarin, M. 2015. Penganggaran Perusahaan. Salemba Empat: Jakarta.

12. Sanjaya, Krisna. 2018. Metode Mudah Memahami Pengantar Ekonomi Makro. Denpasar : CV Dharmastuti

13. Sanjaya, Krisna. 2018. Bali Dalam Narasi. Denpasar : PT Japa Widya Duta

14. Sanjaya, Krisna. 2019 . Ekonomika Uang : Based on Emperical Research. Bandung : CV Sadari.

15. Sastra Wibawa, I. P. (2016). HIGHER EDUCATION LAW CHARACTERLESS PANCASILA. In DHARMA ACARYA FACULTY INTERNATIONAL SEMINAR (DAFIS) PROCEEDING (pp. 166-170). Denpasar: Jaya Pangus Press. Retrieved from http://proceedings.jayapanguspress.org/index.php/dp/article/view/149/149

16. Widani, I., Sanjaya,K,. dan Nuratama. 2018.Pemberdayaan Pengelola Lembaga Ekonomi Komunitas Adat Melalui Penguasaan Teknologi Informasi di Desa Jungut Kabupaten Klungkung Bali. Jurnal Sewaka Bhakti, 2 (1) : 21-34. 